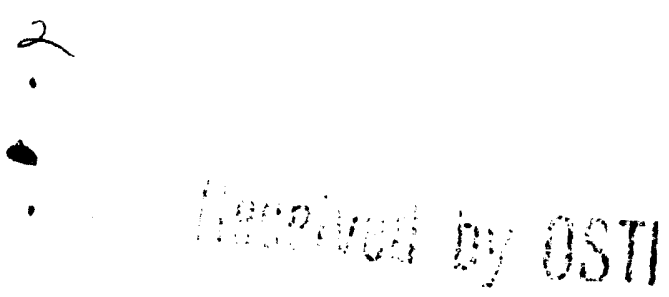

DEC 111990
OAK RIDGE NATIONAL LABORATORY

OPERATED BY MARTIN MARIETTA ENERGY SYSTEMS. INC POST OFFICE BOX 2008, OAK RIDGE, TENNESSEE 37831.6285

Purpose: The purpose of this trip was to meet with members of the Commission of the European Communities to discuss plans for proceeding with parallel projects in the U.S. and Europe to examine the external costs of fuel cycles. This was the second of two planning meetings, the first having been held in Washington, DC on August 1 and 2, 1990.

$\begin{array}{lll}\text { Itinerary: } & 10 / 20-10 / 21 & \begin{array}{l}\text { Travel to Brussels } \\ \text { Brussels }\end{array} \\ 10 / 22-10 / 26 & \\ 10 / 27-10 / 27 & \text { Travel to Knoxville }\end{array}$

Pierre Valette, Commission of the European Communities

Abstract: The Department of Energy (DOE) and the Commission of the European Communities (CEC) have been exploring the possibility of parallel studies on the external costs of employing fuel cycles to deliver energy services. These studies are of particular importance following the activities of the U.S. National Energy Strategy (NES), where the potential discrepancies between market prices and the social costs of energy services were raised as significant policy concerns. To respond to these concerns, Oak Ridge National Laboratory (ORNL) and Resources for the Future (RFF) have begun a collaborative effort for the DOE to investigate the external costs, or externalities, generated by cradle to grave fuel cycle activities. Upon initiating this project, the CEC expressed an interest to the DOE that Europe should conduct a parallel study and that the two studies sliculd be highly coordinated for consistency in the results. This series of meetings with members of the CEC was undertaken to resolve some issues implied by pursuing parallel, coordinated studies; issues that were previously defined by the August meetings. In addition, it was an opportunity for some members of the U.S. research team and the DOE sponsor to meet with their European counterparts for the study, as well as persons in charge of research areas that ultimately would play a key role in the European study. 


\section{Summary of Activities}

Fuel cycle cost analyses have become a subject of considerable interest in the U.S. and Europe as part of the process of producing, transforming, and using energy. More recently, efforts have been launched in the U.S., Canada, Germany, Indonesia, and within the United Nations to address the criticism that conventional fuel cycle assessments do not reflect damages to environmental and health resources. Of primary concern is that the associated environmental costs of using energy fuels are not fully reflected in the price consumers pay for energy services. The "uninternalized" costs, or externalities, ultimately impose a burden on society that arguably, should be borne instead by energy consumers and producers. Other types of externalities associated with energy use include human health impacts and contributions to national energy vulnerability. The extent to which prices fail to reflect externalities may be understood by a comprehensive analysis of all the social costs that are incurred by using energy sources and the various means by which these costs are paid. To respond to the externalities question, the DOE and CEC have undertaken parallel efforts to study the external costs of fuel cycles used to deliver energy services.

The understanding of total fuel cycle cost including externalities is important for informed policy actions to be taken in either encouraging or limiting particular energy options. Environmental impacts of particular fuels may be easily identified, but extremely difficult to measure confidently. Similarly, the full economic costs of impacts that are easily measured may still imply difficult valuation problems. Furthermore, the prices of some fuels already reflect externalities tha have been addressed by regulatory or policy actions. Thus, parallel investigations by the U.S. and Europe require close agreement over numerous analytical decisions that affect the consistency of research results. The meetings in Brussels were the second series of meetings between the CEC and U.S. teams to ensure this close agreement.

\section{Saturday, October 20 and Sunday, October 21}

These two days were spent traveling from Knoxville to Brussels and getting settled at the Hotel Metropole. On Sunday, Robert Shelton and Robin Cantor, ORNL, met with Alan Krupnick, RFF, and Vito Stagliano, DOE to have dinner and plan for the meetings of the next two days.

\section{Monday, October 22 and Tuesday, October 23}

The first two business days of our visit were spent in a meeting between the U.S. and CEC steering groups. In general, the meetings went extremely well. The U.S. team included Vito Stagliano, DOE Office of Policy Integration, Robert Shelton and Robin Cantor, ORNL, and Alan Krupnick, RFF. In addition, Rock Anthony of the U.S. mission to the European Communities attended for the State Department. The CEC participants included: Paolo Fasella, General Director of DG XII; Philippe Bourdeau, DG XII Director, Environment and Non-Nuclear Energy Sources; Pierre Valette, DG XIl Strategies Analysis and Modelling; Matthias Mors, DG II Econometric Models; Francois Govaerts, DG XII Science and Technology; and Werner Balz, DG XII Nuclear Security. Other attendees included: Robert Hill, Newcastle Photovoltaics Applications Center, Newcastle upon Tyne Folytechnic; Yves Smeers, Louvain la Neuve University; Olav 
Hohmeyer, Fraunhofer Institute for Systems and Innovation Research; and Susana Protasio, a contractor to the CEC who took notes.

The CEC participants consisted mostly of program people and those that might play a supporting or steering role for the study, but it was clear that the CEC is not as far along as the U.S. in identifying persons who will actually manage or conduct research for the project. The CEC will benefit from the contributions of Olav Hohmeyer, who has recently completed an externalities study for Germany. In addition, the CEC has recently completed a study of possible membernation responses to limit $\mathrm{CO}_{2}$ emissions that should facilitate the process of identifying the research team for the study of external costs of fuel cycles.

The purpose of the meetings in Brussels was to further agreements between the steering groups about how to proceed with the parallel studies on the externalities of fuel cycles. In this regard, the meetings were highly successful. The U.S. and CEC teams had exchanged several position papers prior to arriving in Brussels, so that proposed responses to research questions were well considered prior to our arrival. This is not to say that all problems were resolved in the two days of meetings. In fact, several new problems were identified that will require an additional three position papers: definitions for externality types, how to treat the discount rate, and how to treat long leadtimes that are characteristic of the coal and nuclear power plants. We agreed to exchange these additional papers by $11 / 15$. We also agreed to a third meeting of the steering groups to be held in the U.S. sometime in March. In the meantime, both groups will encourage frequent and open communication among the research teams to begin the coal analysis for the study immediately.

\section{Wednesday, October 24}

No formal meetings were scheduled for this day for Robin Cantor or Robert Shelton, who used the day preparing for meetings with CEC program people planned for the remainder of the week. Vito Stagliano met with CEC counterparts to discuss an administrative agreement for the parallel studies. Some members of the CEC steering group met with representatives from Japan, which has expressed an interest in joining this collaboration. However, no decision was made regarding this request.

\section{Thursday, October 25}

After the planning meetings, the remainder of the week was spent meeting with key program directors within the CEC. These people will ultimately contribute data and analysis to the externalities study. After a number of such meetings, we felt confident that the CEC supports this effort and that the program people are willing to participate. These discussions were also useful to gauge the level of experience of the technology people in combining environmental and technological analysis. Unlike the U.S., where environmental impact statements or environmental assessments are required for many technology-related activities, Europe has no counterpart to the National Environmental Policy Act (NEPA). Thus, we expect that one important benefit of the studies will be the transfer from the U.S. to the CEC of analytical practices used to assess the environmental as well as the technical and cost consequences of technology decisions.

In the morning Robert Shelton and Robin Cantor met with Armand Colling, DG XVII, Division Cinief, Renewables and Conservation. Mr. Colling explained that DG XVII concentrated 
on five general areas: barriers to efficient energy pricing throughout Europe; energy policies for Europe including standards and performance requirements; fossil energy technologies; non-fossil energy sources; and nuclear safeguards. In the fossil and non-fossil areas there is a major program called THERMIE to encourage the promotion of energy technologies for Europe. This program basically operates by allowing the CEC to grant financial support for high risk projects that promote energy technologies which can potentially benefit all of Europe. THERMIE concentrates funding in four areas: conservation, renewables, solid fuels, and hydrocarbons. In addition there is a preference for projects proposed by at least two independent contributors located in different member countries. Funding for THERMIE in the 1991 budget is about \$177 million dollars.

Lunch and Thursday afternoon were spent with Pierre Valette and members of the Energy Technology Support Unit (ETSU) for the UK Department of Energy. We met Nick Eyre of ETSU who contributed to the recent $\mathrm{CEC}$ study on $\mathrm{CO}_{2}$ emissions for member nations (called $\mathrm{CRASH}$ ). Nick is a very likely candidate to work on the externalities project. He is a physicist by training, now very interested in systems analysis and renewable energy sources.

After lunch, we heard a presentation by the ETSU group on the CRASH results. The study basically applied a linear programming model to minimize the production costs of the electricity supply system given certain constraints on $\mathrm{CO}_{2}$ emissions. The results of the study were not unexpected; member nations with high levels of coal power in their systems have the best potential to reduce $\mathrm{CO}_{2}$ emissions, those with little coal power have fewer opportunities. The modelling attempted to incorporate the potential of conservation to offset some of the adjustments costs; however, conservation was included in a very optimistic fashion, i.e., using engineering cost estimates for the technologies rather than market data and with no formal evaluation of the claims regarding energy savings. What became clear from the discussion was that the U.S. is further along than its European counterparts in formal evaluation and market analysis of conservation options. This may be due to the difference in how prices for electricity act to encourage conservation investments. In Europe, time of day pricing acts to make conservation investments an individual decision, there is little in the way of utility sponsored demand-side management programs. Alternatively, in the U.S., average cost pricing leads many utilities to use demand-side management as a resource to offset capacity additions; therefore, there is more centralized information about the effectiveness and realized costs of conservation investments. We agreed to send Pierre the recent white paper prepared for the NES on how much efficiency might contribute to energy resources.

\section{Friday, October 26}

In the morning we met with Paul Sens, Manager of the Solid Fuels R\&D, DG XII. He discussed with us the Joint Opportunities for Unconventional or Long-Term Energy supply (JOULE) program. In many ways similar to the THERMIE program, JOULE attempts to encourage projects through joint funding arrangements with the CEC as a financial partner. Additionally, JOULE is more R\&D related than THERMIE which emphasizes risky, but commercial ventures. Mr. Sens also explained that his program focuses on the efficiency issue for power plants as a solution to reducing emissions. Thus, he prefers advanced coal options like the magnetohydrodynami. (MHD) concept that is expected to achieve very high (50\% or better) efficiencies to options that perhaps reduce emissions but also achieve low efficiencies. This point of view will become important as we select the technologies considered to be viable investments for analysis in the 2010 scenario of the externalities project. 
Following the meeting with Mr. Sens, we met with Wolfgang Palz, Manager of Renewable Energy Sources, DG XII and Pietro Moncada Peterno Castello of the Biornass Program. They explained to us that the renewables program of the CEC was relatively small, concentrating mostly in wind and small hydro projects. Biomass is expected to play a significant role only in Italy, were several initiatives are under way. Wind power is expected to increase substantially as a major supply of electricity. We also learned that Mr. Palz initiated the Hohmeyer study for Germany.

Next we met with Mr. P. Zegers, Program Manager for Conservation R\&D, and Mr. P. A. Pilavachi, Program Manager in Science, Research and Development. The CEC has a relatively small program in conservation R\&D, concentrating mostly in windows, passive solar heat and passive cooling. They do little on building shells; again, this may be due to the difference in incentives for such actions at the individual level. Mr. Ze gers was enthusiastic about the externalities project and felt he could benefit from a better understanding of the U.S. data on conservation options.

After lunch, we met with Robert De Bauw, Director of Energy Technology, DG XVII. Mr. De Bauw discussed the Specific Actions for Vigorous Energy Efficiency (SAVE) program with us. The SAVE program is a five-year program intended to be the essential core of the EC's energy efficiency policy. SAVE focuses on three areas: technical measures, financial measures, and measures relating to consumer behavior. Additionally, SAVE is very applications-oriented, focusing on short- to medium-term measures for funding. Some of the actions under consideration for funding in the SAVE program include: third party financing proposals; least cost planning implementation; cogeneration proposals; various electricity end-use programs; and informational incentives such as newsletters, databases, information networks, and collaborations with non-EC countries.

Late in the day, we had a wrap-up session with Pierre, where we reviewed the notes of the first two days and discussed our impressions after meeting with CEC staff. We agreed to exchange papers on externality definitions, leadtimes, discount rates, and the preliminary list of coal technologies for analysis as the first fuel cycle by November 15 . We also agreed to supply Pierre with a list of names representing the key points of contact for major research areas for the U.S. team. Finally, we discusser the possibility of hosting the CEC project manager, once this person is named, for a week in Oak Ridge so that he or she can become familiar with us and the activities of the project so far. 
Appendix A: Itinerary

October $20-21 \quad$ Travel to Brussels.

October $22-23 \quad$ Meeting with CEC steering group for externalities project.

October $24 \quad$ Preparations for meetings with CEC program staff.

October 25 Meetings with the Division Chief of Renewables and Conservation, DG XVII.

Participation in the briefing on the CRASH project.

October 26

Meetings with the Manager of the Solid Fuels R\&D, DG XII; the Manager of Renewable Energy, DG XII; the Program Manager of Energy Conservation R\&D, DG XII; and the Director of Energy Technology, DG XVII; and wrap-up with Pierre Valette.

October $27 \quad$ Travel to Knoxville. 
Appendix B: Contacts

Robert Hill, Newcastle upon Tyne Polytechnic, Tel: (091) 232-6002, Fax: (091) 235-8017, Ellison Place

Yves Smeers, Louvain la Neuve Université, Tel: 32.10.474323, Fax: 32.10.474301, 34 Voie du Roman Pays, Louvain la Neuve

Olav Hohmeyer, Fraunhofer Institut fur Systemtechnik und Innovationsforshcung, Tel: (721)68.09.161, Fax: (721)68.91.52, Breslauer Strasse 48, D-7500 Karlsruhe 1

Pierre Valette, Directorate General XII Strategies Analysis and Modelling, Tel: (32) 2.235.63.56, Fax: (32) 2.236.30.26, 200 Rue de la Loi, B-1049 Brussels, Belgium

Philippe Bourdeau, Directorate General XII Director, Environment and Non-nuclear Energy Sources, Tel: (322)235-35-70, Fax: (322)236-30-24, 200 Rue de la Loi, B-1049 Brussels, Belguim

Paolo Maria Fasella, Directorate General XII General Director for Science Research and Development, Tel: (322)235.35.70, Fax: (322)235.76.29, 200 Rue de la Loi, B-1049 Brussels, Belgium

Matthias Mors, Directorate General for Economic and Financial Affairs, Tel: (02) 235.95.89, 200 Rue de la Loi, B-1049 Brussels, Belgium

Francois Govaerts, Directorate General XII Science and Technology Collaboration with Industrialised Countries

Werner Balz, Directorate General XII, Principal Administrator, Division of Nuclear Plant Safety, Directorate for Nuclear Safety Research, Tel: (322) 235.41.64, Fax: (322)236.20.06

Susana Protasio, CEEETA

Vito Stagliano, U.S. Department of Energy, Office of Policy, Planning and Analysis.

Anthony Rock, U.S. Mission to EC

Armand Colling, Chef de division, Commission des Communautés Européennes, Tel: (+322)235.40.87, Fax: (+32-2)235.01.50, 200 Rue de la Loi, B-1049 Brussels, Belgium

Nick Eyre, Chief Scientist's Group, Energy Technology Support Unit, Tel: (0235) 821000 ext 3543, Fax: (0235)432923, B156 Harwell Laboratory, Oxfordshire OX11 ORA

Paul F. Sens, Manager Solid Fuels R. and D., Directorate-General XII, Commission of the European Communities, Tel: +32 (2) 23577 00, Fax: +32 (2) 23630 24, 200, rue de la Loi, B-1049, Brussels, Belgium 
Pietro Moncada Paternó Castello, Directorate General XII Sciences, R. and D., Commission of the European Communities, Tel: 32.2.236.11.23, Fax: 32.2.235.01.45, 200 rue de la Loi, B-1049 Brussels, Belgium

Wolfgang Palz, Directorate General XII, RE, Tel: (322) 235-6922

Ir. P. Zegers, Programme Manager, Directorate General XII, Commission of the European Communities, Tel: (02) 2355845, Wetsraat 200, B-1049 Brussels, Belgium

P.A. Pilavachi, Commission of the European Communities Directorate Generai Lor Science, Tel: 235.36.67, 200 rue de la Loi, B-1049 Brussels

Robert De Bauw, Director, Commission of the European Communities, Tel: $(+32-2) 235.16 .62$, Fax: (+32-2)235.01.50, 200 rue de la Loi, B-1049 Brussels, Eelgium 
Appendix C: Literature Acquired

Commission of the European Communities, Directorate General for Science Research and Development. Biomass for Energy, Industry and the Environment, A Strategy for the Future. Edited by G. Grassi and A. V. Bridgewater. Milano (Italy): Edizioni Esagono - Sesto San Giovanni, 1990.

Commission of the European Communities, Directorate General for Science Research and Development. Joini Opportunities for Unconventional or Long-term Energy Supply (JOULE), Information Packet, 1989-1990.

Commission of the European Communities, Directorate General for Energy. Promotion of Energy Technologies for Europe (THERMIE), September 1990.

"Council Regulation (EEC) No. 2008/90 of 29 June 1990 concerning the promotion of energy, technology in Europe (Thermie Programme)," Official Journal of the Europea.. Communities, L 185, Volume 33, Luxemburg: Office for Official Publications of the European Communities, July 17, 1990.

Palz, Wolfgang. "Renewable Energy in Europe," International Journal of Solar Energy, 1990, Vol. 9, pp. 109-125.

Specific Actions for Vigorous Energy Efficiency (SAVE), Advanced Crpy, COM(90) 365/final, Brussels, October 4, 1990.

\section{DISCLAIMER}

\footnotetext{
This report was prepared as an ac:ount of work sponsored by an agency of the United States Government. Neither the United States Government nor any agency thereof, nor any of their employees, makes any warranty, express or implied, or assumes any legal liability or responsibility for the accuracy, completeness, or usefulness of any information, apparatus, product, or process disclosed, or represents that its use would not infringe privately owned rights. Referenr - herein to any specific commercial product, process, or service by trade lame, trademark, manufacturer, or otherwise does not necessarily constitute or imply its endorsement, recommendation, or favoring by the United States Government or any agency thereof. The views and opinions of authors expressed herein do not necessarily state or reflect those of the United States Government or any agency thereof.
} 

